young in science as Japan. This was the proffer by Sakurai's chemical colleagrues of a number of original papers, some ready and others nearing completion, to be published together as a festal number of the Journal of the College of Science in honour of the event. Together they form nearly half of vol. xxv. of the journal, the rest of the volume, it is of interest to state, consisting of a botanical paper in Latin by 13. Hayata, entitled "Flora Montana Formosæe," and illustrated by forty-one exquisite plates. Prefixed to the copies of the chemical part of the volume which have been issued separately for presentation purposes is a biographical sketch of Sakurai, by Prof. $N$. Matsui, director of the College of Agriculture.

The contents of this publicition are ample evidence of the striking and wonderful success, in the course of relatively few years, of Japan's venture into the field of chemical research. There are seventeen papers, fouching nearly all parts of present chemical investigation, all of them of value as original contributions, some of very considerable value, and most of them fixing the attention. In abstract they are now appearing, or have already appeared, in European journals; any one of them would have been accepted for publication here or in Germany (two are in German). One was partly published at the time of the jubilee in the $B$. $d$. deutschen chom. Ge'sell schaft.

"The Yiscosity of I)ilute Alcoholic Solutions," by T. I Yirata: "Die Anomalie der starkeneinwertigen IElectrolyte," by M. Katavama and "Coasulation of Colloidal Aluminium Hydroxide by Electrolytes," by $S$. Kawamura, are three examples of excellent work. 'Two other papers, "The Fusion Curves of the Sistem, Naphthalene-phenol," and "The Fusion Surfaces of the Sistem, Naphthalene-chlorobenzene-phenol," the post-graduate work of two of Prof. K. Ikeda's pupils, T. Yamamoto and II. Hirose, are also of high excellence. The paper by I'rof. Ikeda himself, on "The Chemical Theory of Solutions," part i., which covers cighty quarto parges, is particularly worthy of attention. It $i s$, in fact, a short tresitise which, when part ii. can be added to it, should have publication in book form, so valuable does it appear to be. It is an exceptionally clear exposition of the subject in admirable English, showing marked originality of treatment, fully illustrated by curves, and mathematically discussed, altogether a most interesting paper.

"The Inversion of Cane-sugar," by Y. Osaka; "Complex Ferrimalonates," by M. Matsui ; "Constitution of Elacomargaric Arid," by 'T. Kametaka; "Japanese Oils," by the same; " Ueber den Hauptbestandteil des japanischen Iacks," by Majima and Cho; "Oximes and Imides of Benzenedisulphonic Acids," by 'T. Suzuki ; "Formation of p-Oxvcarbostyril from $o$-Nitroben\%ovlacetic $\Lambda$ cid," by K. Matsubara; and "Molecular Re-arrangement of N-Benzylbenzaldoxime," by M. Kuhara, are also interesting contributions.

There is a paper br, like Prof. Kuhara, another well-known chemist, Prof. 'T. Haga, entitled "A Simple Method of preparing the Imides of the Aromatic Sulphonic Acids," which is a perfect little piece of work of its kind, admirably written. There are still to be noticed two papers by Prof. M. Ogawa which, from their subjects, will be of sreater general interest than anv other member of this group of Japanese paners, for they seem to establish the existence of two nerw elements among the metals, nipponium, and another not vet named. These papers recently appeared in full in the Chemical Neas. Mr. Ogawa was, two or three vears ago, in London, workings upon the new mineral, thorianite, placed in his hands by Sir William Ramsay. Some of this mineral he took back with him to Japan, where he has discovered other mineral sources of both these elements.

Besides the contents of Sakurai's jubilee part of the Journal of the Tokyo College of Science, other important chemical papers have, from time to time, appeared in that journal, and in English and German journals. I3ut the appearance of this budget of papers on chemical research offers itself now as a striking proof of the remarkable progress which has taken place in the pursuit of chemistry by a nation which, thirty years ago, was nearly ignorant of any significant part of it. That in phisics and in the biological sciences the Japanese have equally advanced under similar conditions is, of course, familiar to many of the readers of Naturf.

EDWIRD I Divers.

\section{THE AGEING OF STEEL.}

A MEIIORANDLM, by Mr. C. E. Stromeyer, the chief engineer of the Manchester Steam Lsers' Association, just issued, doals with the important question of the agreing of steel, especially that used for steam boilers. It is now twenty-five years since mild stiel begran to come into use for boilers; and some definite conclusions have been reached as to its behaviour with time. Tensile and bending tests of steel, cut from boiler plates which have been in use for many years, show that the tenacity has remained practically unaltered, while the ductility, as measured by the elongation, has not been affected. It is known that even the best I owmoor iron boiler plates become brittle with long-continued use, and it is important to know if this happens with steel plates, but no very definite conclusions appear to have been reached, although it was found that the effect of an injury, such as a chisel nick, or a serious deforming pressure, is not an immediate one, except as regards local alteration of thape, but that after the lapse of many weels the nelyhbourhood of the injured region gets somewhat brittle.

A very complete account is also given of the causes which produce water-hammer in steam pipes, and the pressures reached in various cases are worked nut in some detail, showing very conclusively the superiority of mild steel over cast iron for sterim ripes, not only on account of its superior tenacity, but also by reason of its capacity to absorb sudden shock by its clastic and plastic deformation.

\section{NOTES}

We notice with sincere regret the announcement in the daily papers that Lord Rayleigh, who, accompanied by I ady Rayleigh, left Fngland recently for a tour round the world, has been so ill in South Africa that he has abandoned a proposed visit to Australia, and will probably winter in Egypt. Later reports state that, though his lordship has been seriously ill, he is now much better.

TuE one-hundredth anniversary of the birth of Charles Darwin will occur on Friday of next week, February 12. To celebrate this event the New York Academy of Sciences will hold a special meeting on the anniversary day at the American Museum of Natural listory. We learn from Science that in addition to the presentation to the museum of a bust of Darwin-the presentation to be made by Mr. Charles F. Cox, president of the academy, and the acceptance by Dr. Henry F. Osborn, president of the museum-addresses will be given on Darwin's work in botany, by Prof. N. I. Britton; on Darwin's work in zoolog:, by Prof. H. C. Bumpus; and on Darwin's work in geolngy, by Prof. J. J. Stevenson.

$$
\text { No. 2049, voi.. 79] }
$$

